\author{
GREGA STRBAN \\ ORCID: 0000-0002-8369-9376 \\ University of Ljubljana \\ SARA BAGARI \\ ORCID: 0000-0001-5853-3545 \\ University of Ljubljana
}

\title{
RELIANCE ON LONG-TERM CARE AS A "NEW" SOCIAL RISK IN NATIONAL AND EU LAW
}

\begin{abstract}
There have always been people who cannot take care of their daily needs and are reliant on care. However, due to higher life expectancy and low birth rates, changes in lifestyle and increased mobility, reliance on long-term care is becoming a general risk in life. Therefore, it must be provided with social protection. In this respect, the criteria for shaping the (new) social risk of reliance on long-term care are also fulfilled. Although different benefits are already provided within different parts of the social security system, the paper discusses that the best option is to define reliance on long-term care as an independent social risk. Furthermore, we must ensure that providing long-term care will not turn out to be a double social risk. The issue has to be addressed at the national and at the EU level.
\end{abstract}

Keywords: social risk, long-term care, reliance on long-term care, national law, EU law

\section{INTRODUCTORY REMARKS}

As life expectancy is increasing, ${ }^{1}$ the number of elderly people in society is also growing. ${ }^{2}$ More people now reach an age where declining physical and mental health make them dependent on the assistance and care of others. However, not

1 On average for the EU-28, women's life expectancy at birth increased from 72.4 years (1960-1965 period) to 82.6 years (2015-2020 period) and men's life expectancy in the same periods increased from 67.0 years to 77.1 years (European Parliament, Demographic outlook for the European Union 2019, p. 8).

2 People aged 65 or over made up $19.7 \%$ of the population of the EU-28 on 1st January 2018 (Eurostat, Population structure and ageing). Furthermore, the proportion of people aged 80 or over in the EU-28 population is expected to more than double by 2050, reaching $11.4 \%$ (European Parliament, Demographic outlook for the European Union 2019, p. I). 
only elderly people are at risk of the reliance on long-term care. Illness or accidents may also cause younger people to be reliant on long-term care. A modern, faster, and riskier lifestyle that increases the risk of serious injury and illness, could prevent an individual from fulfilling all (or some) daily activities independently. In addition, mobility within the EU is increasing and fertility rates are declining (people are having fewer children). ${ }^{3}$ This causes a reduction in the number of young(er)people who are and will be able to provide long-term care. Long-term care is still mainly provided inside the family, but family members may live further away from their (elderly) relatives and therefore may not be able to provide such care. ${ }^{4}$

For that reason, on the European Union (hereafter "EU") level and in the majority of Member States, there are many discussions about introducing or modernising long-term care schemes. ${ }^{5}$ The European Commission has recognised the need for adaptation of the social protection systems to the needs of the elderly as far back as in the late 1990s. In 2004, the so-called open method of coordination was extended to healthcare and long-term care. The recently adopted European Pillar of Social Rights (hereafter "the EPSR") stresses that "everyone has the right to affordable long-term care services of good quality, in particular homecare and community-based services" (Principle 18 - Long term care). ${ }^{6}$

The question of long-term care opens many legal issues, which are addressed in the paper. It is briefly discussed which risks are in need of social protection and how a social risk differs from a private risk. Considering that reliance on longterm care has outgrown individual risk and has become a social risk, the paper then focuses on reliance on long-term care, for which distinctive notions might be used. In the next step, an analysis is made whether the reliance on long-term care represents (i) a new social risk, (ii) an independent social risk and / or (iii) a double social risk. Finally, the paper focuses on the recent EU response to reliance on long-term care as a social risk.

${ }^{3}$ Data shows that the numbers of children being born in EU-28 average has fallen from around 2.5 children per woman in 1960, to a little under 1.6 today (European Parliament, Demographic outlook for the European Union 2019, p. I).

4 The traditional family structure of more generations living together is not common anymore, more people live in smaller households. In this respect see G. Strban, "Distinctive long-term care schemes as a response to changed family structures and demographic situation", Pravnik 67, 2012, no. 3/4, pp. 249-278.

5 The introduction of long-term care insurance has been under discussion in Slovenia since 2006, when the first legislative proposal was introduced by the Ministry of Health. It was followed by the second proposal by the Ministry of Labour, Family, Social Affairs, and Equal Opportunities in 2010 and the third one by the Ministry of Health in October 2017. The Ministry of Health published the last proposal in August 2020.

6 The EPSR was jointly proclaimed by the European Parliament, the Council and the European Commission in November 2017 (European Commission, Proposal for an Inter-institutional Proclamation on the European Pillar of Social Rights, COM (2017) 251 final). 


\section{RELIANCE ON LONG-TERM CARE AS A SOCIAL RISK}

The purpose of social security is the protection that society provides to its members in the event of a materialisation of social risk that results in a loss or a significant reduction of income or an increase in costs through a process of broader or narrower social solidarity. ${ }^{7}$ However, not all risks in life are social risks and are therefore in need of social protection. ${ }^{8}$ It could be argued that for certain occurrences in life that are rare or even isolated, the State is under no obligation to organise a social protection system. In addition, the attention of private insurance companies will be gained only when such occurrences are numerous enough, but still do not present a general risk to life. Furthermore, a specific risk can be identified as a social risk only when it occurs both frequently and regularly enough in society, so that it influences the free development not only of individuals but of society as such and therefore becomes a general risk of life. ${ }^{9}$ In that case society has to provide (social) security. Hence, social protection, in the form of social insurances, and possibly complemented with other public (social assistance and social compensation) systems has to be organised. ${ }^{10}$

Given the above, we can conclude that reliance on long-term care represents a social risk, that is among the new(er) social risks. For that reason, it still lacks a clear definition and clearly defined benefits on the national level. ${ }^{11}$ Moreover, different notions regarding the risk of reliance on long-term care are being used. However, it is not the risk that is new, but identifying reliance on long-term care as a general risk in life (being numerous enough and occurring on a regular basis in society) that calls for a comprehensive social approach.

At the end of the 1970 s, there was no single term for the phenomenon we call reliance on long-term care today, either in national or in international law and therefore different terms were used. ${ }^{12}$ Terminology developed through the follow-

${ }^{7}$ Social security has to cover persons with different levels of risk and distributes burdens among them.

8 Generally, the notion of risk is interpreted as a future, uncertain event that lies beyond the will of the person involved (D. Pieters, Social Security: An Introduction to the Basic Principles, Alphen aan den Rijn 2006, p. 36) or as the possibility of something bad happening at some time in the future. However, this is not always true for social risks.

9 For more see G. Strban, Social risk, 2020, not yet published.

10 G. Strban, "Odvisnost od oskrbe drugega - novo socialno tveganje? Reliance on long term care - a new social risk", Zbornik znanstvenih razprav 71, 2012, pp. 212-213.

11 Training and Reporting on European Social Security (trESS), Coordination of Long-term Care Benefits - current situation and future prospects, eds. Y. Jorens et al., Think Tank Report 2011, p. 9.

12 For example, in the UK the notion of "being in need of nursing care" was used, in Germany "helplessness" (germ. Hilflosigkeit), and in France the role of a third person (fr. tierce personne) was highlighted as there was a special allowance for care of war victims and recipients of disability pensions (fr. majoration pour tierce personne). 
ing years using different, less and more appropriate terms. ${ }^{13}$ In this respect reliance on long-term care, also used by the CJEU, ${ }^{14}$ seems to be the most appropriate term and is therefore used as such in this paper.

\section{NEW SOCIAL RISK?}

The existence of elderly persons and persons with disabilities who cannot take care of their daily needs is not new. We have always had people who are reliant on care, but there were other social mechanisms that provided it (for example, family members took care of each other). With changing demographic structures, such as children not living in the same place as their parents, the need for society to step in (through social security systems based on solidarity) emerges.

At the international level, traditional social security risks are enshrined in ILO Convention No. 102 on minimum social security standards (1952). The advantage of this Convention is that it has clearly defined the substance of the right to social security, which has been proclaimed as a fundamental human right by certain international legal acts. At the same time, the Convention serves as a role model to other international documents. ${ }^{15}$

For that reason, it could be argued that every risk emerging after 1952, when the ILO Convention No. 102 on minimum standards of social security was passed, is new. Despite the many advantages of Convention No. 102, its shortcomings should also be emphasised. By enumerating (only) nine social risks, it leaves insufficient room for the development of new answers to any new social problems that may arise. ${ }^{16}$ This is why some authors note that reliance on long-term care represents a new social risk. ${ }^{17}$

13 For instance, the term long-term care is used in the UK, the term dependency in France (dépendence) and Spain (dependencia), loss of autonomy (fr. perte d'autonomie) in France and need for care (germ. Pflegebedurftigkeit) in Germany and Austria. The latter (need for long-term care) does not seem to be the most appropriate term, since other social risks are not defined from the viewpoint of the beneficiary and his/her needs either, but also dependency might not be the most accurate solution, because we might connect this term with economic dependency. It could also be mistaken for particular diseases causing dependency (and hence representing the social risk of sickness). Furthermore, every child (depending on his or her age) is to some extent dependent and in need of the care of a parent or guardian, thereby making them dependent (G. Strban, "Legal aspects of long-term care in Slovenia", [in:] Long-Term Care in Europe, A Juridicial Approach, eds. U. Becker et al., Cham 2018, p. 433).

14 See, for example, C-160/96 Molenaar, § 3, or C-388/09 da Silva Martins, § 40.

15 Such as the European Code of Social Security and Regulation (EC) No 883/2004 on the coordination of social security systems and the European Convention on Social Security. Furthermore, the original European Social Charter refers to it when determining a satisfactory level of social security.

16 D. Pieters, op. cit., p. 2.

17 MISSOC Secretariat: MISSOC Analysis, Long-Term Care, Report for the European Commission, Brussels 2009, p. 3. 
The criteria that can be used for creation of new social risk can refer to compliance with international standards, the comparative perspective, or changed social relations, which might cause the imbalance of the social security system.

The question is whether the international duty of the state to provide protection for social risk has to exist first for a new social risk to be created or recognised. International legal acts, on the one hand, follow the development of social security systems in countries. On the other hand, international legal acts may set certain standards that guide the national legislature. Some countries have already recognised an independent social risk of reliance on long-term care and have created special schemes through which they provide protection. ${ }^{18}$

Reliance on long-term care is explicitly mentioned in some international legal acts. Does this mean that all countries that are legally bound by those acts have to provide special protection for the social risk of reliance on long-term care? It can also be noted that some international instruments do not mention reliance on longterm care. This applies to both United Nations (UN) legal acts ${ }^{19}$ and the ILO Conventions. ${ }^{20}$ While some legal acts are legally binding, they only refer to reliance on long-term care at the principle level (legal acts of principles, not content), ${ }^{21}$ intended only to coordinate social security systems, without prejudice to their content, ${ }^{22}$ or they refer to reliance on long-term care indirectly. The latter applies to the revised European Social Charter, laying down the right of elderly persons to social protection. Article 23 of the revised European Social Charter states that the parties undertake to adopt or encourage appropriate measures designed in particular to enable elderly persons to remain full members of society for as long as possible, allowing them to freely choose their lifestyle and live independently in familiar surroundings for as long as they wish and are able to. In addition to health services, the long-term care services of the elderly person's home and adequate support for institutional care are of importance.

${ }^{18}$ For example, long-term care insurance was established in 1995 in Germany and in 1999 in Luxembourg. In Austria two major cornerstones of the Austrian long-term care regime were introduced in 1993, namely the Federal Long-term Care Allowance Act (Bundespflegegeldgesetz) and agreement between the Federal Republic and the federal provinces regarding the responsibility of providing long-term care services (in-kind benefits). See European Commission, ESPN Country Thematic Reports on Challenges in Long-Term Care, Brussels 2018.

19 The Universal Declaration of Human Rights in relation to the right to social security mentions certain social risks (see Article 25), among which there is no reliance on long-term care. However, the path of enabling the right to social security is quite open, as Article 25 states that "Everyone has the right to [...] necessary social services, and the right to security in the event of unemployment, sickness, disability, widowhood, old age or other lack of livelihood in circumstances beyond his control".

${ }^{20}$ Konvencije MOD s komentarjem, eds. M. Novak et al., Ljubljana 2006.

21 See Article 34 of Charter of Fundamental Rights of the European Union.

22 For example Regulation (EC) No 883/2004 on the coordination of social security systems, OJ L 166, 30.4.2004, p. 1. 
Another possible criterion to create a new social risk is the introduction of individual benefits or a specific social security scheme. This is possible for formal reasons, for example based on the norms of international law or based on similar solutions in other jurisdictions.

Probably more important for introducing new benefits or schemes are substantive reasons, when the relations in society change so much that the legislation must follow. There must be a specific number of people in society who are dependent on the care of another for the fulfilment of life's needs, thereby creating an imbalance in the social security system. This is especially evident when more and more people who rely on long-term care find themselves below the poverty line and become recipients of tax-financed social assistance benefits. The legislature is then obliged to act. ${ }^{23}$

The question is whether the criteria for the creation of the social risk of reliance on long-term care are fulfilled in all countries, including Slovenia. Regarding the formal reasons, we can conclude that Slovenia is bound by the aforementioned international norms, the most important of which is the revised European Social Charter. In addition, in many countries with comparable social security law, the changed relations in society have disturbed the balance of the social security system. For example, in many countries ${ }^{24}$ the (elderly) people who are reliant on longterm care often seek this assistance in the form of institutional care, due to lack of family or other informal assistance. As institutional care services are usually not cheap, a pension that has hitherto been sufficient is no longer enough to survive. ${ }^{25}$ Thus, a person was dependent on financial assistance from family members who are obliged to support them or might (for the first time in their life) have to claim social assistance benefits (in the form of exemption from payment of social services or social assistance cash benefit). It was unacceptable that pensioners needed social assistance benefits simply because they needed long-term care, although they had never received (needed) social assistance benefits earlier in life. Therefore, these countries have developed specific schemes. ${ }^{26}$

Furthermore, from a legal point of view, it would be unacceptable for social assistance to become a basic benefit provided for the social risk of reliance on longterm care. Social assistance should only be required in exceptional cases (as the

23 The Slovenian Constitutional Court also notes that the principle of adapting the law to changes in society is one of the principles of the rule of law (Decision of the Slovenian Constitutional Court No. U-I-69/03, 20.10.2005).

${ }^{24}$ Such as Germany, Spain and Austria (G. Strban, "Distinctive long-term care schemes...", pp. 211-238).

25 According to ESPN country reports in nearly all countries, out-of-pocket payments may be required both for home care services and for residential care (S. Spasova et al., Challenges in LongTerm Care in Europe. A Study of National Policies, Brussels 2018, p. 15).

${ }^{26}$ For example the Flemish part of Belgium and Germany have formed a new branch of social security for long-term care, Spain has integrated long-term care services into the national protection system, and Austria has introduced a special long-term cash benefit scheme (federal Pflegegeld). 
last safety net, the net below the net) when other benefits cannot be claimed. The purpose of the social security system, in particular social insurance, is to maintain (even within certain limits) the standard of living in the event of temporary loss (or permanent loss) of income or increased costs.

International legal acts and comparable legal frameworks can provide the basis for recognising the social risk of reliance on long-term care. The fundamental question is whether the relationships in society have changed so much that this is necessary. In this respect, statistics are clear, the population is ageing, ${ }^{27}$ which represents a major change in society. Considering that the number of elderly people has increased in recent years (and will continue to increase further) and the fact that reliance on long-term care is predominantly related to age, we can safely assume that this represents a need to recognise reliance on long-term care as a social risk.

Relationships in society are also affected by lifestyle changes. Multigenerational households that could take care of the family members themselves are rare. There are smaller families, single-person households, couples or (outside) marital communities without children and same-sex partnerships. In addition, various measures aim to encourage economic activity (of women), including the activation of the unemployed, persons with disabilities, widows/widowers and the elderly. Mobility is encouraged within the country and within the Union (for example through coordination of social security systems), which leads to de-territorialisation. Family members or friends no longer live close to each other.

Reliance on long-term care has become one of the general risks of life such as illness, disability, or old age, therefore it must also be provided with social protection. It seems that the criteria for shaping the social risk of reliance on long-term care are also fulfilled.

\section{INDEPENDENT SOCIAL RISK?}

The question remains whether the available measures (already provided in other branches of social security) are sufficient or should reliance on long-term care be considered an independent social risk that needs its own definition and scheme.

Reliance on long-term care is increasingly emphasised as an independent social risk that is separate from other (traditional) social risks, although it is closely related to some of them. ${ }^{28}$ There are quite diverse benefits in kind and cash provided by social security systems to persons reliant on long-term care, even if no special scheme exists. To recognise reliance on long-term care as an independent social risk, we first have to define it.

27 See footnotes in introductory remarks.

28 Such as sickness, invalidity or old age. 
Some understand reliance on long-term care as lost or diminished capability of self-care. Self-care can be described as an activity that people exercise to maintain life, health, and development of their own personalities. This means exercising fundamental life activities and essential activities of daily living. A person who loses or whose capability of self-care is diminished when he or she is unable to independently move (stand up, dress or undress, climb stairs), take care of personal hygiene (to wash, shave, comb, wipe), feed (prepare and consume food) or take care of household chores (wash dishes, do housework, shop, do laundry, etc.). ${ }^{29}$

The OECD has defined long-term care as "a cross-cutting policy issue that brings together a range of services for persons who are dependent on help with basic activities of daily living over an extended period of time." ${ }^{30}$ Furthermore, it states that reliance on long-term care represents a range of services that a person with a reduced level of functional physical or cognitive ability needs, whose dependence on assistance in carrying out the core activities last for a long time. ${ }^{31}$ However, the definition given above mentions only services (benefits in kind), while cash benefits are not mentioned.

From the CJEU case law we can conclude that a person is reliant on care if there is a permanent need to rely, in large measure, on assistance from other persons in the performance of their daily routine. ${ }^{32}$

Considering above mentioned definitions, definitions in national legislations ${ }^{33}$ and definition given within the trESS project, ${ }^{34}$ it is possible to define reliance on long-term care. It means a reduction, loss or non-acquisition or incomplete acquisition of (physically, mental, intellectual or emotional) autonomy due to age, (serious) disease or (grave) invalidity (at any age), which causes the need for (substantive) care over an extended period of time, in order to perform essential activities of daily living.

The legislature can adopt a more general definition and leaves the definition of indeterminate legal concepts to case law or decide for a more detailed legal definition. Determining the levels of reliance on long-term care is also common. ${ }^{35}$

29 E. Eichenhofer, Sozialrecht, Tübingen 2010, p. 207.

30 OECD, Long-term Care for Older People, Paris 2005, p. 9.

31 F. Colombo et al., Help Wanted? Providing and Paying for Long-Term Care, Paris 2011, p. 11.

32 See the ECJ judgement of 5th March 1998 in Case C-160/96 Molenaar, EU:C:1998:84, § 7.

33 Member States might apply distinctive definitions, if they have an official definition at all.

34 In trESS report a general (European) definition covering long-term care benefits is suggested: "Long-term care benefits means benefits for persons who, over an extended period of time, on account of old-age, disease or incapacity, and linked to a lack or loss of physical, mental, intellectual or sensorial autonomy, require assistance from (an)other person(s) or considerable help to carry out essential daily activities." (trESS, op. cit., p. 14).

35 For example, until 2016 in Germany there were three levels of care. With effect from 2017 they were replaced by five care grades based on physical, mental, and psychological disabilities. In Spain there are three different degrees of dependency that are determined according to the fre- 
Whether we consider reliance on long-term care a new risk or not, it must be classified as an independent social risk; this is not only because care has changed qualitatively and quantitatively, but mainly because protection for this social risk cannot be adequately provided anymore with the help of (absent) family members or uncoordinated arrangements in individual branches of the social security system.

This also applies to Slovenian legislation, ${ }^{36}$ where benefits for reliance on long-term care are provided not only in various parts of the social security system, but also outside of it. Long-term care benefits in cash are provided as: (i) an assistance and attendance allowance (dodatek za pomoč in postrežbo) within pension and invalidity insurance, social assistance schemes, protection of the persons with disabilities and social compensation system (for war invalids), (ii) special childcare allowance (dodatek za nego otroka) and (iii) partial payment for lost income (delno plačilo za izgubljeni dohodek) in a family benefits scheme. Furthermore, when a child is born that requires special care and protection, parental leave and parental benefit as well as the right of one parent to work part-time can be prolonged. Benefits in kind are provided in compulsory health insurance (as non-acute medical care) and in social assistance schemes (as social services, domestic care or residential care). ${ }^{37}$

A mixed benefits guarantee system in different parts of the social security system can only lead to partial solutions which unduly burden traditional social security schemes, and makes it hard to establish a comprehensive and internally compliant social policy. The latter has to face reliance on long-term care directly. That is why there is no other (or at least no better) option than to create an independent social risk and providing special social protection. ${ }^{38}$

Reliance on long-term care can be distinguished from illness or injury (workrelated or not). The latter, as a rule, results in a short-term physical or mental disability in the functioning of the human body, which requires medical care or compensation for loss of income. To be identified as a social risk, reliance on long-term care should last for at least a fixed period of time (at least six months), and the need for a more intensive (non-medical) form of care must exist.

Differently, disability (invalidity) is a permanent or lasting (congenital or acquired, physical or mental) disorder in the functioning of the human body that cannot be eliminated through treatment and medical rehabilitation. Despite the

quency and intensity of the assistance required (Moderate or Degree I, Severe or Degree II and High Dependence or Degree III). In Austria, Pflegegeld is granted according to seven different levels that correspond to different levels of individual care requirements or the health status of the person in need of care. See European Commission, ESPN Country Thematic Reports on Challenges in LongTerm Care, Brussels 2018.

${ }^{36}$ About the Slovenian social security system in general see B. Kresal et al., Social Security Law in Slovenia, Alphen aan den Rijn 2016.

37 See G. Strban, "Legal aspects...", pp. 415-460.

38 D. Pieters, op. cit., p. 95. 
sustainability of both social risks, disability and reliance on long-term care are not necessarily related. One major difference is that the goal of invalidity insurance (and other benefits for people with disabilities) is their vocational and employment rehabilitation. So (re) inclusion in (especially working) community life is of the utmost importance. This may be irrelevant to most people in need of long-term care, such as elderly people (who are no longer active in the labour market).

Reliance on long-term care can also be separated from the social risk of old age (which can result in the loss of income). At a certain age, disability (a permanent inability to work) was sometimes assumed. For example, when the first modern pension schemes were introduced in 1889 in Germany, the retirement age was 70 years, although the average life expectancy was only 58 years. ${ }^{39}$ Today, the retirement age is defined as social consent on a specific age at which the individual is no longer required to be economically active. Therefore, even in old age, an individual can be completely healthy and independent, thus independent of the care of another.

Even though reliance on long-term care is defined as an independent social risk, it does not mean that it is not linked to existing, traditional social risks. For example, just as an elderly person or someone with disabilities may become ill, he or she may become dependent on the care of another. In this case, benefits from compulsory health insurance (such as medical devices) and pension insurance (such as old age pension) and long-term care services can be provided at the same time.

\section{DOUBLE SOCIAL RISK?}

Reliance on long-term care may represent a (social) risk not only for the person reliant on long-term care but also for a family member giving such care, or even broader, for a family.

The issue of double social risk is linked to the question of providing long-term care services. Whether social security benefits are provided to the person in cash or in kind, it always means that someone must actually provide care.

Social security systems can encourage that the long-term care is provided by family members. This can be done through cash benefits for the beneficiary, which the latter may retain for themselves or give to the family member. In some countries, the legislator explicitly promotes the willingness of family members to provide long-term care at the beneficiary's home. ${ }^{40}$ However, if cash benefits are

39 W.H. Dawson, Social Insurance in Germany 1883-1911: Its History, Operations, Results, and a Comparison with the National Insurance Act 1911, New York-London 1912, p. 138.

40 See Art. 3 and 4 of German Sozialgesetzbuch (SGB) XI — Soziale Pflegeversicherung. 
significantly lower than the cost of long-term care services, this actually forces family members, especially women, to provide informal long-term care. ${ }^{41}$

Long-term care in today's society is usually provided by a female family member, which might lead to the indirect discrimination of women, as they have to reduce their economic activity or even leave the labour market to provide care for their family members. This can exist only within the nuclear family (for example, spouses and parents and minor children) or extended families (also among adult children and parents, grandchildren and grandparents, among siblings or other relatives). In the latter case, the arrangements are highly heterogeneous. In Slovenia, the duty of adult children to support their parents also exists, although this raises certain concerns. There are more options regarding how adult children can support their parent, from maintenance in kind, living in a shared household (and also providing long-term care) to (financial) help with providing professional care (if costs are not fully covered in the social security system and parents are not able to bear the costs themselves). ${ }^{42}$

If long-term care is provided by family members, they themselves may become in need of community protection, thereby posing a social risk. Countries therefore try to protect them through various measures. These range from special leave schemes, that allow caring relatives to take some time off from gainful employment or to reduce their working time, ${ }^{43}$ providing respite care to allow informal carers to take some holidays and relieve them from care responsibilities, ${ }^{44}$ cash benefits, ${ }^{45}$ social insurance coverage or consideration of periods of care in the social insurance period or in tax credits for replacement care. Furthermore, various measures aim to improve the quality of care, which is always harder to ensure training and control within informal care. On the other hand, some argue that family members should be relieved and that the majority of care services should be taken over by professional organisations and individuals providing home and residential care. ${ }^{46}$

One of the reasons for that is in the changed relations in society. Nowadays, there is a plurality of lifestyles, which makes the model of one (male) breadwinner of the family (also set out in ILO Convention No. 102 as a starting point) outdated. The pattern of how men and women spend their time in gainful employment and non-profit caring for family members depends on the different historical, political, economic, legal, and cultural circumstances in each country.

${ }^{41}$ In most countries long-term care still heavily relies on the support provided by informal carers. Furthermore, in many countries, most beneficiaries use the cash benefit to pay an informal carer, although often in combination with the use of formal homecare services. (Ibid., p. 17).

42 G. Strban, "Legal aspects...”, p. 457.

43 S. Spasova, op. cit., p. 7.

44 Ibid., p. 18.

45 According to the ESPN country reports only limited number of countries grant cash benefits directly to the carer, for example, Czech Republic, Finland, Hungary, Ireland and United Kingdom (Ibid., p. 7).

46 Ibid. 
Therefore, it may be more appropriate to provide long-term care benefits in kind (with the option of choosing a professional long-term care provider, similarly to what is already known in the healthcare services). Benefits in kind (or earmarked cash benefits) would avoid additional social risk, namely the risk of informal (family) care providers in addition to the reliance on long-term care. This would encourage more equal and genuine family ties in comparison to when family members (especially women) have to provide long-term care directly (which should be carried out continuously or at least to a considerable extent). This can be very burdensome (for instance, in the case of care for people with dementia). Therefore, there is a need for properly trained professional care providers, which also makes it easier to control the quality of care. This, of course, does not exclude the concerns of family members who are bound by a close family bond to the person in need of care. Nevertheless, family members should be able to live their lives as well.

\section{THE EU-LEVEL APPROACH TO LONG-TERM CARE}

Countries have taken different approaches to the social protection of persons reliant on long-term care and national legislations vary greatly. ${ }^{47}$ However, as the challenge is the same for all Member States, ${ }^{48}$ long-term care has recently also gained importance in EU law.

As already mentioned, the right to long-term care is listed in the EPSR as one of its core principles. The Pillar prioritises homecare and community-based services, but also emphasises that having a well-developed and qualitatively good residential sector is important in order to provide support in all those cases where homecare is not viable. Although the EPSR is not legally binding, it aims to trigger legislative and non-legislative activity at the national level, as well as expressing the joint commitment of the EU institutions to act at the EU level. Thus, it represents an opportunity (a first step, so to say) to develop more ambitious action on the EU level to respond to the challenges of the risk of reliance on long-term care ${ }^{49}$. Furthermore, long-term care is gaining importance in the most important social security coordination instrument. In December 2016, the European Commission put forward a proposal to amend Regulation (EC) 883/2004 on the coordination of social security systems and its executive Regulation (EC) 987/2009. ${ }^{50}$ The re-

47 Some comparative aspects have already been mentioned in this paper. For a detailed legal comparison see Long-Term Care in Europe...; S. Spasova, op. cit.

48 Population ageing is a long-term trend which began several decades ago in Europe and the share of the population aged 65 years and over is increasing in every EU Member State, EFTA country and candidate country (Eurostat, Population structure and ageing, July 2019).

49 S. Spasova, op. cit., p. 5.

50 The envisaged revision of Regulation 883/2004 has, however, been blocked by the Council and subsequently postponed by the European Parliament. 
vision aims to establish a coherent regime for the coordination of long-term care benefits by introducing a separate chapter for their coordination in Regulation (EC) No $883 / 2004,{ }^{51}$ by including a definition of long-term care benefits ${ }^{52}$ and list of benefits in each Member State. ${ }^{53}$ According to new rules long-term care benefits for insured persons and members of their families need to be coordinated according to specific rules which, in principle, follow the rules applicable to sickness benefits, in line with the case law of the CJEU. ${ }^{54}$

Just recently, on 13th June 2019, the Council adopted Directive (EU) 2019/1158 on work-life balance for parents and carers and repealing Council Directive 2010/18/EU. ${ }^{55}$ The Directive recognises the right to carers' ${ }^{56}$ leave of five working days per year and emphasises that

Member States should take into consideration that the equal uptake of family-related leave between men and women also depends on other appropriate measures, such as [...] long-term care services, which are crucial for the purpose of allowing parents, and other persons with caring responsibilities to enter, remain in, or return to the labour market and (among others).

Given the above, it could be concluded that more attention is also being given to the risk of reliance on long-term care in EU legal instruments (soft and hard law).

\section{CONCLUDING THOUGHTS}

Due to socio-demographic changes, there is a growing consensus among EU Member States about the importance of social protection for the social risk of reli-

${ }^{51}$ Long-term care benefits have so far not been included explicitly within the material scope of Regulation (EC) No 883/2004 but were coordinated as sickness benefits. This means that the Member State of insurance provides long-term care benefits in cash and reimburses the cost of benefits in kind provided by the Member State of residence.

${ }^{52}$ Long-term care benefits are thereby defined as "any benefits in kind, cash or a combination of both for persons who, over an extended period of time, on account of old-age, disability, illness or impairment, require considerable assistance from another person or persons to carry out essential daily activities, including to support their personal autonomy; this includes benefits granted to or for the person providing such assistance."

53 In order to avoid the overlap of benefits for the same purpose and the same time period. For more see European Commission, Proposal for a regulation amending Regulation (EC) No 883/2004 on the coordination of social security systems and regulation (EC) No 987/2009 laying down the procedure for implementing Regulation (EC) No 883/2004, COM(2016) 815 final.

54 See amendment to Article 1 and new CHAPTER 1a - Long-term care benefits.

55 OJ L 188, 12. 7. 2019. Member states have to transpose the provisions into national law by 2nd August 2022.

56 A carer is thereby defined as "a worker providing personal care or support to a relative, or to a person who lives in the same household as the worker, and who is in need of significant care or support for a serious medical reason, as defined by each Member State." 
ance on long-term care. Distinctive approaches have been developed in (different) countries and the topic is starting to gain importance in EU legal instruments as well.

The social risk of reliance on long-term care is not entirely new and different benefits (in kind or in cash) are already provided within different branches of the social security system, as reliance on long-term care is closely related to some (traditional) social risks. However, what has changed is the rising number of persons who require assistance with the basic activities of daily living, creating a need for recognising reliance on long-term care as risk in need of social protection (social risk). Furthermore, the criteria for the creation of the social risk of reliance on long-term care as an independent social risk from existing ones are met.

As mentioned, relations in society have significantly changed, causing the imbalance of the social security system, which should reflect these changes. The population is ageing, and family members are not necessarily living in proximity to provide care that is needed. Even if family members live close to or even in the same household with a person in need of long-term care, providing such care may be of considerable physical, mental, and emotional strain to them and it may restrict their freedom. Therefore, the involvement of an increased number of professional carers in long-term care is essential. The person who is in need of long-term care has the right to freely choose their lifestyle and stay in the home environment if he or she so desires. Care can be provided by family members (if they freely decide so). However, the duty of society as a whole is to ensure that providing long-term care will not turn out to be a double social risk.

Reliance on long-term care should be defined as an independent social risk and benefits (in kind or in cash with an obligation to spend it on care) should be provided in a more transparent and effective manner. They should enable a decent living of a person reliant on care and not overburden the lives of informal carers.

\section{ZALEŻNOŚĆ OD OPIEKI DŁUGOTERMINOWEJ JAKO „NOWE” RYZYKO W PRAWIE KRAJOWYM I PRAWIE UNII EUROPEJSKIEJ}

\section{Streszczenie}

Od zawsze istnieli ludzie, którzy nie mogli zadbać o swoje codzienne potrzeby i polegali na opiece innych osób. Jednak ze względu na oczekiwaną większą długość życia i niski wskaźnik urodzeń zmiany w sposobie życia i zwiększoną mobilność, poleganie na opiece długoterminowej staje się powszechnym ryzykiem życiowym. Stąd też konieczność zapewnienia określonej ochrony socjalnej. Pod tym względem kryteria ukształtowania (nowego) ryzyka socjalnego zależności od opieki długoterminowej są spełnione. Choć różnorodne świadczenia są już przewidziane w różnych działach systemu zabezpieczenia społecznego, najlepszym rozwiązaniem, przyjętym w niniejszym opracowaniu, jest zdefiniowanie zależności od opieki długoterminowej jako niezależnego ryzyka 
społecznego. Ponadto należy zadbać, aby długoterminowa opieka nie okazała się podwójnym ryzykiem społecznym. Problem ten należy rozwiązać na szczeblu krajowym i unijnym.

Słowa kluczowe: ryzyko socjalne, opieka długoterminowa, zależność od opieki terminowe, prawo krajowe, prawo Unii Europejskiej

\section{BIBLIOGRAPHY}

Colombo F. et al., Help Wanted? Providing and Paying for Long-Term Care, Paris 2011.

Eichenhofer E., Sozialrecht, Tübingen 2010.

European Commission, ESPN Country Thematic Reports on Challenges in Long-Term Care, Brussels 2018, https://ec.europa.eu/social/main.jsp?advSearchKey=espnltc_2018\&mode=advanced Submit $\&$ catId $=22 \&$ policyArea $=0 \&$ policyAreaSub $=0 \&$ country $=0 \&$ year $=0$ (accessed: 10.12 .2019$)$.

European Commission, Proposal for a Regulation of the European Parliament and of the Council amending Regulation (EC) No 883/2004 on the coordination of social security systems and regulation (EC) No 987/2009 laying down the procedure for implementing Regulation (EC) No 883/2004, COM(2016) 815 final.

European Parliament, Demographic outlook for the European Union 2019, https:/www.europarl. europa.eu/RegData/etudes/IDAN/2019/637955/EPRS_IDA(2019)637955_EN.pdf (accessed: 10.12.2019).

Eurostat, Population structure and ageing, July 2019; https://ec.europa.eu/eurostat/statistics-explained/index.php/Population_structure_and_ageing\#The_share_of_elderly_people_continues to increase (accessed: 10.12.2019).

Konvencije MOD s komentarjem, eds. M. Novak et al., Ljubljana 2006.

Long-Term Care in Europe, A Juridical Approach, eds. U. Becker et al., Cham 2018.

MISSOC Secretariat: MISSOC Analysis, Long-Term Care, Report for the European Commission, Brussels 2003.

OECD, Long-term Care for Older People, Paris 2005.

Pieters D., Social Security: An Introduction to the Basic Principles, Alphen aan den Rijn 2006.

Spasova S., Baeten R., Coster S., Ghailani D., Peña-Casas R. and Vanhercke B., Challenges in longterm care in Europe. A study of national policies, Brussels 2018.

Strban G., "Distinctive long-term care schemes as a response to changed family structures and demographic situation", Pravnik 67, 2012, no. 3/4, pp. 249-278.

Strban G., "Legal aspects of long-term care in Slovenia", [in:] Long-Term Care in Europe, A Juridical Approach, eds. U. Becker et al., Cham 2018, pp. 415-460.

Strban G., "Odvisnost od oskrbe drugega — novo socialno tveganje? Reliance on long term care a new social risk", [in:] Zbornik znanstvenih razprav 71, 2012, pp. 212-213.

Strban G., Social risk, 2020, not yet published.

Training and Reporting on European Social Security (trESS), Coordination of Long-term Care Benefits - Current Situation and Future Prospects, eds. Y. Jorens et al., Think Tank Report 2011. 